\title{
Changes in Growth Variables and Potassium Content in Leaves of Black Barley in Response to $\mathrm{NaCl}$
}

\author{
Mariam A. Abu-Al-Basal ${ }^{1}$ and Bassam T. Yasseen ${ }^{2 *}$ \\ ${ }^{1}$ Department of Biological Sciences, Faculty of Science, Al-al-Bayt University, Mafraq, Jordan \\ e-mail.m_basal@yahoo.com \\ ${ }^{2}$ Department of Biology, College of Science, Mosul University, Mosul, Iraq \\ e-mail.bassam_tahaa@yahoo.co.uk \\ ${ }^{2}$ The previous address of the second author \\ * Corresponding author: \\ ${ }^{3}$ Petunia Court, Dorrington Close, Luton, Beds, LU3 1XT, UK \\ Landline: 00441582486672 \\ Received: 20 June 2009; Accepted: 12 December 2009.
}

\begin{abstract}
Much attention is being focused on the Black barley (Hordeum distichum L.) as a local cultivar offering good model for a cereal crop has traits of resistance to drought and salinity during vegetative growth stages. Although Black was sensitive to salt stress during germination, it developed gradual tolerance with age and proved very tolerant during growth and development stages. The data of study clearly revealed how this cultivar was superior over Arivat (Hordeum vulgare L.) in many physiological aspects such as leaf growth variables (i.e. rate and duration) and processes (i.e. cell division), tiller production and potassium content. Black barley had more tillers, faster rate and longer duration of growth processes which was accompanied with potassium accumulation, as sodium chloride concentration increased in the growth medium. Thus, the ability of Black cultivar to accumulate $\mathrm{K}^{+}$could have promoted growth variables (i.e. faster rate and longer duration of growth processes). Arivat, on the other hand, might have suffered from $\mathrm{K}^{+}$deficiency; which could explain the adverse effect of salt stress on leaf growth variables and processes. Moreover, the relative water content (RWC) and proline can clearly distinguish the two cultivars; RWC was higher and proline concentration was lower in leaves of Black as compared with Arivat. Therefore, Black barley proved efficient in maintaining growth, ion homeostasis, and might sacrifice less in growth under osmotic stress conditions. The possible mechanism of the effect of sodium chloride on potassium accumulation in Black barley is discussed.
\end{abstract}

Key words: Black barley, Hordeum distichum L., cell division, growth rate, growth duration, leaf growth, Arivat, Hordeum vulgare L., potassium, salt stress

\section{INTRODUCTION}

Much attention has been paid to wild plants (Yasseen and Al-Thani, 2007; Yasseen and Abu-Al-Basal, 2008) and local crop plants (Yasseen, 2001) to use germplasm techniques (Flowers, 2004) to transfer resistance traits from them to cultivated varieties. Black barley is a local cultivar that was developed a long time ago as a major cereal crop in different parts of Iraq for various purposes. Its salt tolerance and mechanisms used to cope with saline environments have 
not been studied extensively, but, it proved to be a cultivar sensitive to water stress at the germination stage (Yasseen and Al-Omary, 1994), although it might develop gradual resistance with age during the vegetative and yield stages (Yasseen and Al-Maamari, 1995). One of the main characteristics of cereal crops to cope with osmotic stress is the length of the growing season (Torres-B et al., 1974; Torres-B and Bingham, 1973; Yasseen, 1983; Yasseen and Al-Omary, 1994). In fact, early reports concluded that increasing the length of the growing season, and if leaves are able to expand rapidly under stress conditions, may lead to a considerable maintenance of yield under these conditions (Monteith, 1977). Moreover, leaf growth and ion homeostasis have been considered as key crucial physiological variables in evaluating the resistance of plants in response to osmotic stress conditions (Yasseen, 1983; Zhu et al., 1998; Tardieu et al., 2005), which could lead to adopting modern technologies to improve salt tolerance of crop plants (Flowers, 2004; Shabala and Cuin, 2007). Faster rates, and longer duration, of growth of individual leaves were found in Mexican wheats of the long season cultivars. These are salt tolerant, compared with the short season ones, which are salt susceptible (Yasseen, 1983). Such characteristics have been considered as important criteria in selecting barley cultivars suitable for cultivation in water stressed soils, and for breeding programs to develop drought tolerant cultivars of barley (Yasseen and Al-Omary, 1994). Potassium, proved to have considerable effect on the rate and duration of leaf growth (Rao, 1986; Ouknider et al., 1991), which could have great influence on growth and yield stability under stress conditions. Potassium was found to accumulate in the shoots of Black barley as the soil matric potential decreased (Yasseen and AlMaamari, 1995). The growing bulk of evidence demonstrates that the ability of a plant to retain $\mathrm{K}^{+}$may be crucial in achieving high salt tolerance (Shabala and Cuin, 2007). However, little is known about the possible role of sodium salts in promoting potassium accumulation. Therefore, the present study was carried out to evaluate the response of Black barley; (Hordeum distichum L.; Iong season cultivar) of Iraqi origin, and Arivat; (Hordeum vulgare L.; short season cultivar) of USA origin, to salt stress during germination and vegetative stages. Many physiological variables were included in the evaluation, with special emphasis on the possible role of potassium $\left(\mathrm{K}^{+}\right)$on the growth variables.

\section{MATERIALS AND METHODS}

Grains of barley cultivars (Black and Arivat) were brought from Testing Certification Branch, The Ministry of Agriculture, Mosul, Iraq. Viability tests showed that 98 to $100 \%$ of these grains were viable. Before the germination test, healthy uniform grains were sterilized with $10 \%$ Clorox (sodium hypochlorite) for 2-3 minutes, thoroughly rinsed with distilled and were left to dry.

Germination study: Lots of 25 grains were placed in covered Petri dishes (11 cm in diameter) upon two layers of filter paper, and moistened either with $10 \mathrm{ml}$ distilled water (control), or a salt solution. Three salt concentrations ( 0 , 200 and $400 \mathrm{~mol} \mathrm{~m}^{-3} \mathrm{NaCl}$ ) were used in this experiment. One extra filter paper was placed on the grains inside each Petri dish. All treatments are replicated four times. Petri dishes were placed in a dark incubator at $20^{\circ} \mathrm{C}$. The following growth variables were measured: germination of grains and mean radicle length were determined after five days of treatment. Cell volume in the root tips was determined by weighing a certain amount of tissue and treating it with 10\% chromic acid for three days (Yasseen, 1983) and then followed by the procedure of Sunderland (1960). The following equation was used to estimate cell volume:

$$
\text { Cell volume }=\frac{\text { Fresh weight } / \text { Cell density }}{\text { Cell number }}
$$

Mitotic Index (MI) was estimated in the tips of the germinating grains according to the procedure described elsewhere (Sharma and Sharma, 1965) with some modifications of using the staining agent basic fuchsine.

\section{Vegetative growth study:}

\section{Growth conditions}

Grains were germinated in trays of Perlite and watered with distilled water, and seedlings of uniform size were transferred to aerated nutrient solution when they had two leaves. Modified Long Ashton nutrient solution was used in these experiments; iron was supplied as a combination of $0.1 \mathrm{~mol} \mathrm{~m}^{-3}$ Fe-EDTA and $0.0144 \mathrm{~mol} \mathrm{~m}^{-3}$ ferrous sulfate. The nutrient solution was changed after two weeks of use. Four concentrations of $\mathrm{NaCl}$ were used; $0,50,100$, and 200 $\mathrm{mol} \mathrm{m}{ }^{-3}$, and the treatments were replicated four times. The experiments were done in a glasshouse under natural light 
conditions, with a range maximum temperature between 20 to $25^{\circ} \mathrm{C}$, and a range minimum temperature between 5 to $10^{\circ} \mathrm{C}$. The average relative humidity ranged from 45 to $65 \%$.

\section{Leaf growth}

The lengths of the fourth and sixth leaves were measured from the first day of appearance until growth had stopped. A linear description of laminar growth was used as described by Gallagher (1979):

$F_{L}=\left(R_{L} \times D_{L}\right)+L_{i}, F_{L}$ is the final length, $R_{L}$ is the mean laminar extension rate, $D_{L}$ is the duration of growth, and $\mathrm{Li}$ is the laminar length at the beginning of growth $\left(0.1 \mathrm{~F}_{\mathrm{L}}\right) . \mathrm{R}_{\mathrm{L}}$ (cm day $^{-1}$ ) was obtained from the slope of the linear regression of the length of a leaf (cm; on $Y$ axis) and time from appearance (days; on $\mathrm{X}$ axis):

$Y$ ( length of a leaf) $=a+b X$ (days; time from appearance).

$D_{\llcorner}$was obtained from the equation:

$$
D_{L}=\frac{0.9 F_{L}}{R_{L}}
$$

The area of leaves was estimated by a method described by Watson (1937) and then used widely (Yasseen et al., 1987; Yasseen and Al-Omary, 1994; Yasseen and Al-Maamari, 1995). Dry weight or fresh weight was converted to area $\left(\mathrm{cm}^{2}\right)$. In this study the following equations were used: Area $\left(\mathrm{cm}^{2}\right)=0.42 \times$ Dry weight $(\mathrm{mg})$ for Black, and Area $\left(\mathrm{cm}^{2}\right)=$ $0.39 \times$ Dry weight $(\mathrm{mg})$ for Arivat.

The area of leaves on the main tillers and the number of tillers in both cultivars were determined at two growth stages (leaf 4 and leaf 6 stages). These stages were determined when leaves 4 and 6 were fully expanded (after 23 and 35 days of treatment, respectively).

Cell number and cell volume: the method described by Sunderland (1960), and modified by Yasseen (1983) was used to estimate the number of cells, and volume of cells in the individual leaves was estimated using the equation mentioned above.

Ionic content: plant samples (roots and leaves) were dried at $85^{\circ} \mathrm{C}$ for 4 days and then ground. Wet digestion with a mixture of nitric acid and perchloric acid was used to prepare solutions for the determination of $\mathrm{Na}^{+}, \mathrm{K}^{+}$, and $\mathrm{Ca}^{2+}$. The detail of the procedure was described by
Chapman and Pratt (1961). The concentrations of these elements in the plant samples were determined by atomic absorption spectrophotometer (Pye Unicam Ltd, UK). Chloride concentration was determined according to Mohr's method (Johnson and Ulrich, 1959). The ground samples were extracted with double distilled water, and the aliquots were titrated with silver nitrate using potassium chromate as indicator.

Relative Water Content (RWC): RWC of the expanded leaves was determined according to the method of Turner (1981).

Proline: the method described by Bates et al. (1973) was used to estimate proline in fully expanded leaves.

Both RWC and proline were determined in the same leaf samples at the leaf six stage.

\section{RESULTS}

Black barley was very sensitive to salt stress at the germination stage; its germination percentage showed a sharp reduction in the $400 \mathrm{~mol} \mathrm{~m}^{-3} \mathrm{NaCl}$ treatment, while Arivat grains gave more than $70 \%$ germination at that level of salt concentration (Table 1). This finding was supported by other parameters; for example Arivat had longer radicle length, high $\mathrm{Ml}$ and larger cell volume at all salt concentrations as compared with Black barley. However, the response of Black to salt stress changed dramatically at the vegetative stage. It gave more tillers and larger area of leaves on the main tillers and the statistical analysis showed significant differences between the two cultivars; the local cultivar seemed to develop gradual resistance with age (Table 2). For example, high salt stress $\left(200 \mathrm{~mol} \mathrm{~m}^{-3}\right.$ $\mathrm{NaCl}$ ) reduced the area of leaves at leaf four stage by 50 and $25 \%$ in Black and Arivat respectively. At leaf six stage, however, such reduction became 61 and $23 \%$ in those cultivars respectively, at the same salt level. Such results were explained by the growth analysis of leaves as shown in Table (3); the data revealed big differences between the cultivars in the area and length of individual leaves (leaves four and six). Such differences can be explained mainly by the great reduction in the number of cells while the reduction in the cell volume did not show clear consistency with age. It is interesting to emphasise that the adverse effect of salt 
stress were more obvious in the growth rate, which became more pronounced at leaf 6 stage. Growth rate of individual leaves showed great reduction in both cultivars at increased salt concentration in the growth medium. However, leaves of Black seemed to have faster growth rate than those of Arivat, which could explain the significant differences $(p<0.001)$ in the total leaf area between the cultivars studied. Data of growth duration, on the other hand, showed highly significant differences between the cultivars and salt levels. Leaves of Black barley had longer growth duration than those of Arivat. Such differences were more obvious with increasing salt concentration in the growth medium (Table 3; Fig. 1).

Table 1. Germination \%, mean radicle length $\left(\mathrm{mm}\right.$ radicle $\left.{ }^{-1}\right)$, Mitotic Index $(\mathrm{Ml})$, and cell volume $\left(\mathrm{mm}^{3} \times 10^{6}\right)$ of Black barley and Arivat in response to salt stress.

\begin{tabular}{|c|c|c|c|c|c|c|c|c|c|c|c|c|}
\hline \multirow{3}{*}{ Cultivar } & \multicolumn{12}{|c|}{$\mathrm{NaCl}\left(\mathrm{mol} \mathrm{m}^{-3}\right)$} \\
\hline & \multicolumn{3}{|c|}{ Germination \% } & \multicolumn{3}{|c|}{ Radicle Length } & \multicolumn{3}{|c|}{ Mitotic Index } & \multicolumn{3}{|c|}{ Cell Volume } \\
\hline & 0 & 200 & 400 & 0 & 200 & 400 & 0 & 200 & 400 & 0 & 200 & 400 \\
\hline Black & 100 & 42 & 7 & 75 & 18 & * & 15.2 & 10.2 & $\star \star$ & 80 & 62 & $\star \star$ \\
\hline Arivat & 100 & 97 & 71 & 84 & 30 & 6 & 16.7 & 13.1 & 7.5 & 95 & 72 & 33 \\
\hline Treatment: & \multicolumn{3}{|c|}{$p<0.001$} & \multicolumn{3}{|c|}{$p<0.001$} & \multicolumn{3}{|c|}{$p<0.001$} & \multicolumn{3}{|c|}{$p<0.001$} \\
\hline Cultivars: & \multicolumn{3}{|c|}{$p<0.001$} & \multicolumn{3}{|c|}{$p<0.001$} & \multicolumn{3}{|c|}{$p<0.001$} & \multicolumn{3}{|c|}{$p<0.001$} \\
\hline Interaction: & \multicolumn{3}{|c|}{$p<0.001$} & \multicolumn{3}{|c|}{ n.s. } & \multicolumn{3}{|c|}{$p<0.001$} & \multicolumn{3}{|c|}{$p<0.001$} \\
\hline
\end{tabular}

*Not measurable; ${ }^{\star *}$ Not done

Table 2. The effect of salt stress on the area of leaves $\left(\mathrm{cm}^{2}\right.$ plant $\left.{ }^{-1}\right)$ on main tillers of both barley cultivars

\begin{tabular}{|c|c|c|c|c|c|c|c|c|}
\hline \multirow{3}{*}{ Cultivar } & \multicolumn{8}{|c|}{$\mathrm{NaCl}\left(\mathrm{mol} \mathrm{m}^{-3}\right)$} \\
\hline & \multicolumn{4}{|c|}{ Leaf 4 stage } & \multicolumn{4}{|c|}{ Leaf 6 stage } \\
\hline & 0 & 50 & 100 & 200 & 0 & 50 & 100 & 200 \\
\hline \multirow[b]{2}{*}{ Black } & 58 & 53 & 41 & 29 & 89 & 85 & 61 & 54 \\
\hline & $(100)$ & (91) & (70) & (50) & $(100)$ & $(96)$ & (69) & (61) \\
\hline \multirow{2}{*}{ Arivat } & 62 & 43 & 27 & 16 & 80 & 53 & 31 & 18 \\
\hline & $(100)$ & (69) & (44) & (25) & $(100)$ & (66) & (39) & (23) \\
\hline Salt: & \multicolumn{4}{|c|}{$p<0.001$} & \multicolumn{4}{|c|}{$p<0.001$} \\
\hline Cultivars: & \multicolumn{4}{|c|}{$p<0.001$} & \multicolumn{4}{|c|}{$p<0.01$} \\
\hline Interaction: & \multicolumn{4}{|c|}{$p<0.001$} & \multicolumn{4}{|c|}{$p<0.001$} \\
\hline
\end{tabular}

Figures in parenthesis indicate percentages of control

Table 3. Changes in growth variables of two individual leaves of two barley cultivars in response to salt stress

\begin{tabular}{|c|c|c|c|c|c|c|c|}
\hline \multirow{2}{*}{ Growth variables } & \multirow{2}{*}{$\begin{array}{c}\text { NaCl conc. } \\
\left(\mathrm{mol} \mathrm{m}^{-3}\right)\end{array}$} & \multicolumn{3}{|c|}{ Leaf 4} & \multicolumn{3}{|c|}{ Leaf 6} \\
\hline & & Black & Arivat & Signif. Level & Black & Arivat & Signif. Level \\
\hline \multirow{2}{*}{ Tiller number } & 0 & 4.70 & 2.10 & * & 8.60 & 3.60 & $\star \star$ \\
\hline & 200 & - & - & n.s. & 2.10 & 0.20 & * \\
\hline \multirow{2}{*}{ Area $\left(\mathrm{cm}^{2}\right.$ leaf $\left.^{-1}\right)$} & 0 & 15.50 & 8.90 & $\star \star$ & 31.20 & 8.20 & $\star \star *$ \\
\hline & 200 & 9.20 & 3.90 & $\star \star$ & 18.70 & 1.70 & $\star \star \star ~$ \\
\hline \multirow{2}{*}{ Cell number $\left(10^{6}\right)$} & 0 & 3.98 & 2.86 & $\star \star$ & 9.97 & 2.78 & $\star \star \star$ \\
\hline & 200 & 2.99 & 1.29 & $\star \star \star ~$ & 7.39 & 0.54 & $\star \star \star ~$ \\
\hline \multirow{2}{*}{ Cell volume $\left(\mathrm{mm}^{3}\right)$} & 0 & 75.00 & 71.00 & * & 62.00 & 49.00 & $\star \star$ \\
\hline & 200 & 52.00 & 52.00 & n.s. & 42.00 & 39.00 & n.s. \\
\hline Growth rate & 0 & 4.33 & 4.19 & n.s. & 5.69 & 3.20 & $\star \star \star$ \\
\hline$\left(\mathrm{cm}^{\mathrm{day}}{ }^{-1}\right)$ & 200 & 2.36 & 2.19 & n.s. & 3.11 & 1.21 & $\star \star \star$ \\
\hline \multirow{2}{*}{ Growth duartion (days) } & 0 & 5.30 & 4.10 & * & 5.70 & 3.80 & $\star \star \star ~$ \\
\hline & 200 & 6.60 & 4.20 & * & 7.10 & 3.90 & $\star \star \star$ \\
\hline \multirow{2}{*}{ Final length (cm) } & 0 & 25.10 & 19.10 & $\star \star$ & 36.00 & 13.20 & $\star \star \star$ \\
\hline & 200 & 19.40 & 10.80 & $\star \star$ & 24.80 & 5.10 & $\star \star \star$ \\
\hline
\end{tabular}

"t" test was used to compare the means of the two barley cultivars n.s. not significant, ${ }^{*} p<0.05,{ }^{* *} p<0.01,{ }^{* * *} p<0.001$ 

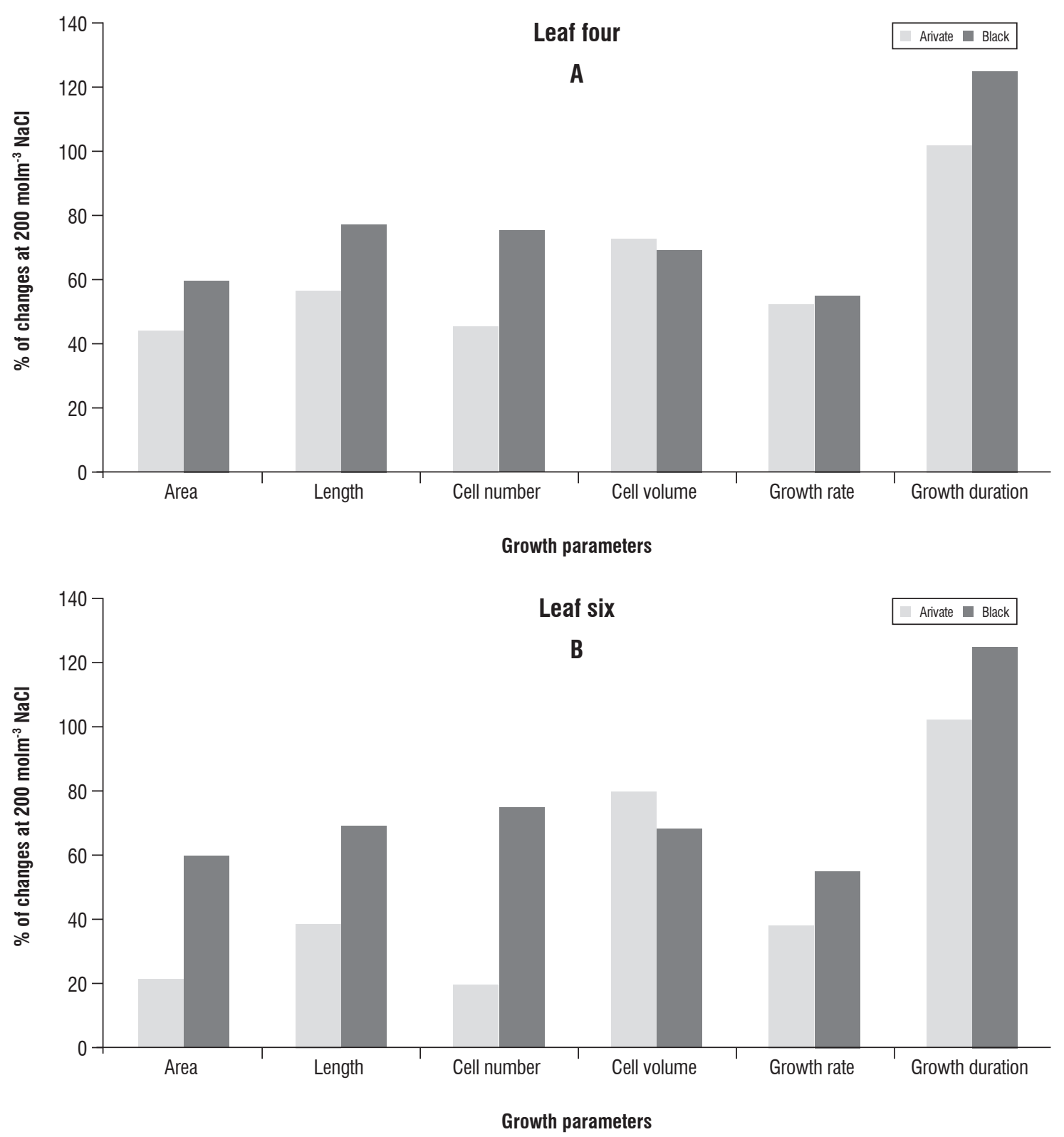

Figure 1. The responses of growth parameters at $200 \mathrm{~mol} \mathrm{~m}^{-3} \mathrm{NaCl}$ (\% of control) of leaf 4 (A) and Leaf 6 (B) of the two barley cultivars

Therefore, it can be concluded that the faster rate and longer duration of growth processes, especially cell division, in leaves of Black barley could have led to the significant superiority of this cultivar over Arivat.

Data for ionic content of leaves and roots are shown in Tables 4 and 5 . As NaCl concentration increased in the growth medium, $\mathrm{Na}^{+}$and $\mathrm{Cl}^{-}$increased substantially, with no clear differences between cultivars. $\mathrm{Ca}^{2+}$ concentration in the plant tissues showed substantial reduction with salinity, however. $\mathrm{K}^{+}$showed an unexpected response. Leaves of Black barley accumulated $\mathrm{K}^{+}$as $\mathrm{NaCl}$ increased in the growth medium, and the concentration of $\mathrm{K}^{+}$increased gradually and consistently with salt stress, while the opposite happened in leaves and roots of Arivat which showed gradual reduction as $\mathrm{NaCl}$ 
increased in the growth medium. It is interesting to note that $\mathrm{K}^{+}$concentration did not change in roots of Black barley at all salinity levels.

It should be noticed that $\mathrm{K}^{+}$concentration and the ratio $\mathrm{K}^{+} / \mathrm{Na}^{+}$in the leaves and roots of the control treatment of Arivat were very high as compared with those of Black. Much reduction in that ratio and the concentrations of $\mathrm{Na}^{+}$and $\mathrm{K}^{+}$ were observed, as $\mathrm{NaCl}$ increased in the growth medium of the first cultivar as compared with those of the second one. However, the $\mathrm{K}^{+} / \mathrm{Na}^{+}$ratio remained above one unit in leaves of both cultivars at all salt concentrations.
RWC and proline were measured in the expanded leaves at leaf 6 stage (Table 6); RWC showed gradual decrease as sodium chloride increased in the growth medium. Statistical analysis showed clearly that cultivars differed significantly $(p$ $<0.01$ ). The data for proline concentration, on the other hand, revealed substantial accumulation $(p<0.001)$ in leaves of both cultivars; such accumulation was gradual and consistent with increasing salt concentration in the solution culture, which was accompanied by a gradual reduction in RWC $(p<$ 0.001). It is interesting to emphasise that while Arivat leaves accumulated much proline as compared with those of Black, RWC of leaves of the latter cultivar was less affected.

Table 4. The effect of salt stress on the content of some elements ( $\mathrm{mg} \mathrm{g}^{-1}$ dry weight) in the leaves of two barley cultivars

\begin{tabular}{|c|c|c|c|c|c|c|c|c|c|c|}
\hline \multirow{2}{*}{$\mathrm{NaCl}\left(\mathrm{mol} \mathrm{m}^{-3}\right)$} & \multicolumn{2}{|c|}{$\mathrm{Na}^{+}$} & \multicolumn{2}{|c|}{$\mathrm{K}^{+}$} & \multicolumn{2}{|c|}{$\mathrm{K}^{+} / \mathrm{Na}^{+}$} & \multicolumn{2}{|c|}{$\mathrm{Ca}^{2+}$} & \multicolumn{2}{|c|}{$\mathrm{Cl}^{-}$} \\
\hline & Black & Arivat & Black & Arivat & Black & Arivat & Black & Arivat & Black & Arivat \\
\hline 0 & 13.3 & 4.8 & 24.6 & 49.9 & 1.9 & 10.4 & 11.9 & 10.0 & 6.5 & 9.0 \\
\hline 50 & 24.1 & 16.3 & 27.8 & 39.7 & 1.2 & 2.4 & 6.7 & 7.0 & 18.0 & 23.3 \\
\hline 100 & 27.4 & 21.9 & 32.1 & 34.6 & 1.2 & 1.6 & 5.4 & 6.8 & 29.3 & 31.8 \\
\hline 200 & 28.6 & 25.0 & 40.9 & 31.7 & 1.4 & 1.3 & 5.3 & 4.4 & 43.3 & 46.0 \\
\hline Salt: & \multicolumn{2}{|c|}{$p<0.001$} & \multicolumn{2}{|c|}{ n.s. } & \multicolumn{2}{|c|}{$p<0.001$} & \multicolumn{2}{|c|}{$p<0.001$} & \multicolumn{2}{|c|}{$p<0.001$} \\
\hline Cultivars: & \multicolumn{2}{|c|}{$p<0.001$} & \multicolumn{2}{|c|}{$p<0.001$} & \multicolumn{2}{|c|}{$p<0.001$} & \multicolumn{2}{|c|}{ n.s. } & \multicolumn{2}{|c|}{$p<0.01$} \\
\hline Interaction: & \multicolumn{2}{|c|}{ n.s. } & \multicolumn{2}{|c|}{$p<0.001$} & \multicolumn{2}{|c|}{$p<0.001$} & \multicolumn{2}{|c|}{ n.s. } & \multicolumn{2}{|c|}{ n.s. } \\
\hline
\end{tabular}

Table 5. The effect of salt stress on the content of some elements ( $\mathrm{mg} \mathrm{g}^{-1}$ dry weight) in the roots of two barley cultivars

\begin{tabular}{|c|c|c|c|c|c|c|c|c|c|c|}
\hline \multirow{2}{*}{$\mathrm{NaCl}\left(\mathrm{mol} \mathrm{m}^{-3}\right)$} & \multicolumn{2}{|c|}{$\mathrm{Na}^{+}$} & \multicolumn{2}{|c|}{$\mathrm{K}^{+}$} & \multicolumn{2}{|c|}{$\mathrm{K}^{+} / \mathrm{Na}^{+}$} & \multicolumn{2}{|c|}{$\mathrm{Ca}^{2+}$} & \multicolumn{2}{|c|}{$\mathrm{Cl}^{-}$} \\
\hline & Black & Arivat & Black & Arivat & Black & Arivat & Black & Arivat & Black & Arivat \\
\hline 0 & 9.3 & 3.6 & 16.4 & 42.2 & 1.8 & 11.7 & 6.9 & 6.4 & 3.0 & 2.3 \\
\hline 50 & 27.4 & 21.1 & 16.0 & 30.3 & 0.6 & 1.4 & 4.4 & 3.6 & 12.3 & 10.8 \\
\hline 100 & 27.7 & 36.6 & 15.0 & 17.1 & 0.5 & 0.5 & 3.7 & 3.4 & 14.8 & 20.3 \\
\hline 200 & 34.4 & 37.5 & 16.3 & 16.2 & 0.5 & 0.4 & 3.1 & 3.4 & 30.5 & 32.0 \\
\hline Salt: & \multicolumn{2}{|c|}{$p<0.001$} & \multicolumn{2}{|c|}{$p<0.001$} & \multicolumn{2}{|c|}{$p<0.001$} & \multicolumn{2}{|c|}{$p<0.01$} & \multicolumn{2}{|c|}{$p<0.001$} \\
\hline Cultivars: & \multicolumn{2}{|c|}{ n.s. } & \multicolumn{2}{|c|}{$p<0.001$} & \multicolumn{2}{|c|}{$p<0.05$} & \multicolumn{2}{|c|}{ n.s. } & \multicolumn{2}{|c|}{ n.s. } \\
\hline Interaction: & \multicolumn{2}{|c|}{$p<0.001$} & \multicolumn{2}{|c|}{$p<0.001$} & \multicolumn{2}{|c|}{$p<0.05$} & \multicolumn{2}{|c|}{ n.s. } & \multicolumn{2}{|c|}{ n.s. } \\
\hline
\end{tabular}

Table 6. The RWC and Proline content in the leaves of two barley cultivars in response to salt stress at leaf 6 stage

\begin{tabular}{|c|c|c|c|c|}
\hline \multirow{2}{*}{$\mathrm{NaCl}\left(\mathrm{mol} \mathrm{m}^{-3}\right)$} & \multicolumn{2}{|c|}{ Relative Water Content (RWC) } & \multicolumn{2}{|c|}{ Proline ( $\mu \mathrm{g} \mathrm{g} \mathrm{g}^{-1}$ fresh weight) } \\
\hline & Black & Arivat & Black & Arivat \\
\hline 0 & 97.2 & 95.7 & 34.5 & 40.3 \\
\hline 50 & 97.0 & 92.1 & 46.1 & 62.1 \\
\hline 100 & 93.7 & 88.5 & 162.5 & 192.4 \\
\hline 200 & 89.4 & 85.2 & 350.7 & 482.5 \\
\hline Salt: & \multicolumn{2}{|c|}{$p<0.001$} & \multicolumn{2}{|c|}{$p<0.001$} \\
\hline Cultivars: & \multicolumn{2}{|c|}{$p<0.001$} & \multicolumn{2}{|c|}{$p<0.001$} \\
\hline Interaction: & \multicolumn{2}{|c|}{$p<0.001$} & \multicolumn{2}{|c|}{$p<0.001$} \\
\hline
\end{tabular}




\section{DISCUSSION}

The outcomes of the study revealed that Black barley offers a good model for a cereal crop and has traits of salt tolerance during vegetative growth stages and perhaps at the productivity and yield stages (Yasseen and Al-Omary, 1994; Yasseen and Al - Maamari, 1995). The data of the study showed clearly how this cultivar was superior over Arivat in many physiological aspects like growth variables (i.e. rate and duration) and processes (i.e. cell division), tiller production and potassium content of leaves under salt stress. Although, Black barley was sensitive to osmotic stress at the germination stage, it developed gradual tolerance to salinity as it passed the seedling stage toward the vegetative stages. Such findings support the hypothesis that tolerance to environmental stresses is not consistent, and may change, over various stages of a plant's life cycle (Wenzel and van den Berg, 1987). It was obvious that Black was more salt tolerant at leaf six stage than at leaf four stage. A similar conclusion was obtained from previous studies when Black was compared with other barley cultivars under water stress; it proved superior over CM-72, Clipper and Arivat at vegetative growth and yield stages (Yasseen and Al-Omary, 1994; Yasseen and Al-Maamari, 1995).

In the present study three parameters can clearly distinguish Black and Arivat; these included growth rate and duration of cell division, and $\mathrm{K}^{+}$content of leaves, the parameters that have been considered as promising crucial keys in developing salt tolerant crops (Rao, 1986; Lefebvre, 1989; Zhu et al., 1998; Flowers, 2004). However, a huge number of published works over the last five decades have confirmed that the presence of sodium salts in the soil would prevent the absorption of potassium, thereby plants might suffer from $\mathrm{K}^{+}$deficiency (Yasseen, 1983; Botella et al., 1997; Mengel et al., 2001; Shabala and Cuin, 2007). Such a conclusion could be valid for Arivat, as shown by the data of the ionic content, since $\mathrm{Na}^{+}$competes with $\mathrm{K}^{+}$ for major binding sites in many key metabolic processes in the cytoplasm, such as enzymatic reactions, protein synthesis and ribosome functions, and more than 50 cytoplasmic enzymes are activated by $\mathrm{K}^{+}$(Benlloch et al., 1994; Marschner, 1995). The growing bulk of evidence has demonstrated that the ability of a plant to retain $\mathrm{K}^{+}$in the cytosol may be crucial in achieving increased salt tolerance
(Lefebvre, 1989; Zhu et al., 1998; Rascio et al., 2001). Scientists are trying to develop crop plants (like cereals) that have efficient mechanisms to maintain high levels of potassium in leaves under salt stress (Zhu et al., 1998; Schachtman and Liu, 1999; Shabala and Cuin, 2007). So far, a considerable number of studies have presented two possible mechanisms to maintain optimal cytosolic $\mathrm{K}^{+}$/ $\mathrm{Na}^{+}$ratio by either: (1) restricting $\mathrm{Na}^{+}$accumulation in plant tissues, (2) preventing $\mathrm{K}^{+}$loss from the cell. However, the unusual accumulation of potassium in the leaves of the Black cultivar, as $\mathrm{NaCl}$ concentration increased in the solution culture, could be possibly because the high-affinity potassium $\left(\mathrm{K}^{+}\right)$uptake transporters (HKT) were activated by the sodium salt (Rubio et al., 1995). Also, it has been recognized that $\mathrm{K}^{+} / \mathrm{Na}^{+}$ratio is a determinant factor in the ability of a plant to survive saline environments (Cramer et al., 1991; Botella et al., 1997). Arivat retained high $\mathrm{K}^{+}$ in roots and leaves in the control treatment (non-saline), which might explain its superiority over the Black cultivar in yield under normal soil irrigation conditions (Yasseen and Al-Omary, 1994). Black barley proved superior over other cultivars during vegetative growth (Yasseen et al., 1987) and yield stages under water stress conditions because of a faster rate and longer duration of leaf growth, which was accompanied by potassium accumulation as soil matric potential decreased (Yasseen and Al-Omary, 1995; Yasseen and Al-Maamari, 1995). It is very likely that the ability of Black barley to accumulate $\mathrm{K}^{+}$might provide this cultivar with traits of improved growth variables (i.e. faster rate and longer duration of growth processes) under osmotic stress (Ouknider et al., 1991; Itoh et al., 1997). This needs further investigation to explore the activity of plant $\mathrm{K}^{+}$-permeable cation transporters (Mäser et al., 2002) under salt stress in Black barley to draw clear conclusion about the mechanism of effect of sodium salts on growth parameters (variables and processes).

Proline accumulated substantially in leaves as sodium chloride concentration increased in the growth medium. However, the two cultivars differed in their response to salt stress; much proline was found in Arivat. Proline as a compatible osmolyte accumulates in the cytosol as a protective mechanism, to balance the ions of $\mathrm{Cl}^{-}$and $\mathrm{Na}^{+}$ that might accumulate in the vacuole (Yasseen, 1992). However, potassium found in leaves of Black barley can be considered as an inorganic compatible osmolyte, and might 
partially fulfill the requirements for osmotic balance across the tonoplast (Delauney and Verma, 1993, Thiery et al., 2004), and could have contributed to maintaining growth rate and duration of growth processes under salt stress. Moreover, potassium accumulation in Black barley leaves could have played a role in improving water status (Rascio et al., 2001) and saving carbon skeletons and the energy of assimilates to build new cells instead of synthesizing molecules like proline to maintain osmoregulation (Bernstein, 1963; Epstein, 1983; Yasseen, 1992; Abbas, 2008). Finally, it can be concluded that the adverse effects of salinity on various physiological and biochemical aspects in plants can come from the differences in the methods of osmotic adjustment and osmoregulation in plant tissues, and the differences between plant species in achieving osmotic adjustment could explain the differences in salt tolerance. Black barley proved efficient in maintaining growth, ion homeostasis, and sacrificed less growth under salt stress conditions.

Acknowledgements: We thank Miss J. Abdul-Khaliq for technical assistance. The linguistic check was done by Dr. David J. Pilbeam at the University of Leeds, United Kingdom.

\section{REFERENCES}

Abbas RAA (2008) Changes in soluble sugars and proline in germinating grains of barely in response to salinity and temperature. Jordan, Al-al-Bayt University. MSc. Thesis.

Bates LS, Wadleigh RP, Teare ID (1973) Rapid determination of free proline for water- stress studies. Plant and Soil 39:205 - 207.

Bernstein L (1963) Osmotic adjustment of plants to saline media. II. Dynamic phase. Amer. J. Bot. 50 (4): 360 - 370.

Benlloch M, Ojeda MA, Ramos J, Rodriguez-Navarro A (1994) Salt sensitivity and low discrimination between potassium and sodium in bean plants. Plant and Soil 166(1):117 - 123.

Botella MA, Martinez V, Pardines J, Cerda A (1997) Salinity induced potassium deficiency in maize plants. J. Plant Physiol. 150:200 - 205.

Chapman HD, Pratt PF (1961) Methods of analysis for soils, plants and waters. Div Agr Sci Univ Calif Berkeley, California.

Cramer GR, Epstein E, Läuchli A (1991) Effects of sodium, potassium and calcium on salt-stressed barley. 2. Elemental analysis. Physiol. Plant. 81:197 $-202$.

Delauney JA, Verma DPD (1993) Proline biosynthesis and osmoregulation in plants. Plant Journal 4:215-223.

Epstein E (1983) Crops tolerant of salinity and other mineral stresses. In: Ciba Foundation Symposium 97, Better crops for food, pp. 61-82. Pitman, London.

Flowers TJ (2004) Improving crop salt tolerance. J. Exp. Bot. 55(396):307 -319 .
Gallagher JN (1979) Field studies of cereal leaf growth. I. Initiation and expansion in relation to temperature and ontogeny. Journal of Experimental Botany 30(4):625 - 636 .

Itoh R, Yamagishi J, Ishii R (1997) Effects of potassium deficiency on leaf growth, related water relations and accumulation of solutes in leaves of soybean plants. Jpn. J. Crop Sci. 66(4):691-697.

Johnson CM, Ulrich A (1959) Analytical methods for use in plants analysis. University of California, Agricultural Experimental Station. Bull., 766.

Lefebvre DD (1989) Increased potassium absorption confers resistance to group IA cations in rubidium - selected suspension cells of Brassica napus. Plant Physiol. 91: 1460 - 1466.

Marschner H (1995) The mineral nutrition of higher plants. Academic Press, London.

Mäser P, Gierth M, Schroeder JI (2002) Molecular mechanisms of potassium and sodium uptake in plants. Plant and Soil 247 (1): $43 \square 54$.

Mengel K, Kirkby EA, Kosegarten H, Appel T (2001) Principles of Plant Nutrition. $5^{\text {th }}$ ed. International Potash Institute, Worblaufen - Bern, Switzerland.

Monteith JL (1977) Climate and the efficiency of crop production in Britain. Philos. Trans. R. Soc. 281: 277-294.

Ouknider M, Jacquard P, Elkhyari D (1991) Concurrence chez Vicia sativa L. et Avena sativa L. II. Effets des contraintes hydriques et nutritionnelles sur la biomasse et la distribution des ressources. Agronomie 11: 821-828, DOl: 10.1051/agro:19911001

Rao NR (1986) Potassium requirements for growth and its related processes determined by plant analysis in wheat. Plant and Soil 96 (1): $125-131$.

Rascio A, Russ M, mazzucco L, Platani C, Nicastro G, Difonzo N (2001) Enhanced osmotolerance of a wheat mutant selected for potassium accumulation. Plant Science 160 (3): 441 - 448.

Rubio F, Gassmann W, Schroeder Jl (1995) Sodium-driven potassium uptake by the plant potassium transporter HKT1 and mutations conferring salt tolerance. Science 270 (5242): 1660 - 1663.

Schachtman D, Liu W (1999) Molecular pieces to the puzzle of the interaction between potassium and sodium uptake in plants. Trends in Plant Science 4 (7): $281-287$

Shabala S, Cuin TA (2007) Potassium transport and plant salt tolerance. Physiol. Plant. 133: 651-669.

Sharma AK, Sharma A (1965) Chromosome techniques- Theory and practice. Butterworht and Co. Ltd., London.

Sunderland N (1960) Cell division and expansion in the growth of the leaf. J. Exp. Bot. 11(31): $68-80$.

Tardieu F, Reymond M, Muller B, Granier C, Simonneau T, Sadok W, Welcker C (2005) Linking physiological and genetic analyses of the control of leaf growth under changing environmental conditions : Modelling complex traits for plant improvement. Australian Journal of Agricultural Research 56 (9): 937-946.

Thiery L, Leprince A-S, Lefebvre D, Ghars MA, Elise Debarbieux E, Savouré A (2004) Phospholipase D Is a Negative Regulator of Proline Biosynthesis in Arabidopsis thaliana. J. Biol. Chem. 279 (15):14812-14818.

Torres-B C, Bingham FT (1973) Salt Tolerance of Mexican Wheat. I. Effect of $\mathrm{NO}_{3}$ and $\mathrm{NaCl}$ on Mineral Nutrition, Growth, and Grain Production of Four Wheats. Soil Science Society American Proceeding 37: 711 - 715.

Torres-B C, Bingham FT, Oertli J (1974) Salt Tolerance of Mexican Wheat. II. Relation to variable sodium chloride and length of growing season. Soil Science Society American Proceeding 38: 777-780.

Turner NC (1981) Techniques and experimental approaches for the measurement of plant water status. Plant and Soil 58:339 - 366 .

Watson DJ (1937) The estimation of leaf area in field crops. J. Agric. Sci. $27: 474-483$. 
Wenzel WG, Van Den Berg WJ (1987) Leaf water retention of excised leaves as a measure of drought resistance in grain Sorghum (Sorghum bicolor $\mathrm{L}$. Moench) genotypes. South Africa J. Plant Soil 4 (1):31 - 34.

Yasseen BT (1983) An analysis of the effects of salinity on leaf growth in Mexican wheats. UK, The University of Leeds. Ph. D. thesis.

Yasseen BT (1992) Physiology of water stress in plants. The University of Mosul, University Press, Iraq.

Yasseen BT, Abu-Al-Basal MA (2008) Ecophysiology of Limonium axillare and Avicennia marina from the coastline of Arabian Gulf-Qatar. Journal of Coastal Conservation: Planning and Management 12(1):35-42

Yasseen BT, Al-Maamari BKS (1995) Furthet evaluation of the resistance of black barley to water stress: Preliminary assessment for selecting drought resistant barley. J. Agronomy \& Crop Science 174: 9- 19.
Yasseen BT, Al-Omary SS (1994) An analysis of the effects of water stress on leaf growth and yield of three barley cultivars. Irrig. Sci. 14:157 - 162.

Yasseen BT, Al-Thani RF (2007) Halophytes and associated properties of natural soils in the Doha area, Qatar. Aquatic Ecosystem Health and Management (AEHMS ) 10: 320 - 326.

Yasseen BT, Jurgees JA, Sofajy SA (1987) Changes in some growth processes induced by $\mathrm{NaCl}$ in individual leaves of two barley cultivars. Indian J. Plant Physiology 30:1- 6.

Zhu J-K, Liu J, Xiong L (1998) Genetic analysis of salt tolerance in Arabidopsis: Evidence for a critical role of potassium nutrition. Plant Cell 10:1181 - 1192. 